\title{
Invited author \\ Professional preparation in physical education: Changing labor market and competence
}

\author{
Go Tani \\ University of São Paulo, Brazil
}

\begin{abstract}
Professional preparation is indeed a complex and dynamic process because it involves a number of interacting elements, which change in time. The objective of the present essay is to analyze the professional preparation in physical education, with the focus on the relation between the very dynamic labor market and the required competence of the professionals to deal with the associated demands. There is no doubt that the professional preparation must not aim to train professionals to merely repeat means for solving practical problems, but professionals with the capacity to repeat the process of solving problems. Consequently, professional preparation programs need to be formative instead of informative and prepare professionals capable of using scientific thinking and method to solve practical problems of intervention.
\end{abstract}

Keywords: physical education, professional preparation, labor market, body of knowledge

Resumo- “Formação profissional em educação física: Mercado em transformação e competências.” A preparação profissional é de fato um processo complexo e dinâmico porque envolve a participação de vários elementos que interagem e mudam com o tempo. O objetivo do presente ensaio é analisar a preparação profissional com o foco na relação entre o mercado de trabalho em constante transformação e as competências exigidas do profissional para responder às demandas a ela associadas. Não há dúvida de que a preparação profissional não deve visar à formação de um mero repetidor de meios para solucionador problemas práticos, mas sim de um profissional com capacidade de repetir o processo de solucionar problemas. Por conseguinte, o curso de preparação profissional necessita ter um caráter formativo e não informativo para preparar profissionais capazes de usar o pensamento e o método científicos para solucionar os problemas práticos da intervenção.

Palavras-chaves: educação física, preparação profissional, mercado de trabalho, corpo de conhecimentos

Resumen-“Capacitación en educación física: la transformación del mercado y las competencias.” La preparación profesional es de hecho un proceso complejo y dinámico, ya que implica la participación de varios elementos que interactúan y cambian con el tiempo. El objetivo del presente trabajo es analizar la preparación profesional con un enfoque en la relación entre el mercado de trabajo en constante transformación y las competencias del profesional requeridas para satisfacer las demandas asociadas a ella. No hay duda de que la preparación profesional no debe ser dirigida a la formación de un mero repetidor de maneras de solucionar problemas prácticos, pero si a un profesional con la capacidad de repetir el proceso de resolución de problemas. Por lo tanto, el curso de preparación profesional debe tener un carácter formativo y no informativo para preparar profesionales capaces de utilizar el pensamiento y el método científicos para resolver los problemas prácticos de la intervención.

Palabras claves: educación física, preparación profesional, mercado de trabajo, cuerpo de conocimientos

\section{Initial considerations}

The social, cultural, scientific, economic, and political transformations of the modern society are increasingly intense and fast. These transformations have imposed enormous challenges to the university to stay connected, to answer the demands emanated from them, and even to induce new demands, in a competent and responsible way.

The role of the university is still object of discussion in the academic environment (Tani, 2007), and it will probably never cease taking into consideration the aforementioned transformations. However, there is a general agreement that the university must carry out three essential activities: teaching, research and community services (e.g. Rollemberg, 2005; Steiner \& Malnic, 2006).

Regarding the teaching activities, the main purpose of the university is to prepare professionals for the labor market through undergraduate courses. Professional preparation is indeed a complex and dynamic process because it involves a number of interacting elements, which change in time. Social needs, labor market, institution's physical and administrative structure, body of knowledge, teaching staff, proposal of undergraduate program, and student staff can be considered some of the elements that participate and influence the preparation of professionals (Tani, 2007).

The objective of the present essay is to analyze the 
professional preparation in physical education, with the focus on the relation between the very dynamic labor market and the required competence of the professionals to deal with the associated demands. Opportune to mention that the purpose of this essay is not to present a comprehensive analysis of the competencies involved in the articulation of professional knowledge, skills, perceptions and attitudes, but to analyze the competence specifically related to the theoretical and scientific knowledge of the area. The reason for this delimitation is that physical education is still an incipient field of knowledge that has peculiarities concerning the production, systematization, organization and dissemination of knowledge that have important implications to the professional preparation.

\section{Physical education as a profession}

We can classify professions according to different criteria. In relation to the criterion of expected, required and demanded preparation for professional practice, they can be either technically or academically oriented professions. Technically oriented professions require a high school educational level, usually offered by secondary technical schools. On the other hand, academically oriented professions demand training in university's undergraduate programs (Tani, 2008).

Physical education belongs to the academically oriented professions, and professionals apply basically three types of knowledge in their interventions: 1) scientific knowledge produced by the formal study of movement/physical activity/ physical exercise; 2) personal knowledge acquired by the experience in movement/physical activity/physical exercise; and 3) professional knowledge developed by the professional practice with movement/physical activity/physical exercise.

Although physical education professional intervention requires the usage of these three types of knowledge, the social and professional credibility of an academically oriented profession depends on the legitimacy of the academic body of knowledge that supports the professional practice. The legitimacy of the body of knowledge, in its turn, presupposes the existence of a structure to orient and organize the production, systematization, dissemination and application of knowledge, that is, an epistemological basis that can evidence and define the identity of the area (Tani, 1996).

Nevertheless, several uncertainties remain concerning the academic identity of physical education In fact, the area needs a profound epistemological reflection to define the body of knowledge that yields legitimacy to the profession and professional preparation. As this subject was object of reflection in the previous articles (Tani, 1988, 1989, 1996, 1998, 1999, 2006, 2008, 2010, 2011), we suggest to interested people to access the original articles. It is only worth to register here that the area has produced a significant amount of knowledge, but its real potential to effectively support the professional intervention needs further reflections.

\section{The university crises and professional preparation}

It is widely recognized that the university influences and has been influenced by the historical, social, cultural, economic and political contexts of each period. At each of these moments, the university dealt with specific problems, challenges and obstacles. Presently, the university faces a very special challenge caused by two main factors that put the institution in a true crisis: a) the contemporary vertiginous increase in the production of scientific knowledge (knowledge revolution); and b) the remarkable evolution in information technology concerning wideness, and agility of information transmission (communication revolution) (Tani, 2011).

In a conservative perspective, the word crisis would not threaten the university. As an institution dedicated to the production of new knowledge, the university always challenges the unknown world, working at the frontier of knowledge. Everyone who operates under this circumstance is in fact in a permanent state of crisis in the sense that he constantly experiences the sensation that the acquired competence is not sufficient to cope with new challenges.

However, the knowledge and communication revolutions are frightening the university. The university has lost the hegemony of knowledge, especially in relation to their dissemination, causing serious implications to their production. In the past, before the communication revolution, it was compulsory to go to the university to access the historically produced and accumulated knowledge by the different scientific disciplines, but this is not true nowadays. The invention of the computer and the subsequent advances in the information technology turned the visit to the University into a waste of time, if the objective is simply to access knowledge. There are several institutions more efficient than the university in giving access to knowledge both in terms of quantity and speed. The Internet symbolizes all of these institutions that have put the university in a terrible crisis. There is no doubt that it is better for the student to stay home and use the Internet to access knowledge. In this scenario, it is opportune to ask the actual role of the university in the teaching domain.

In order to overcome this crisis, the university needs to offer more than the access to knowledge and work in areas where other institutions have evident limitations. This implies the reevaluation of the potentialities and competences of the university.

Regarding the Internet, the problem is that it enables the access to knowledge indiscriminately. It does not demand any selection criteria. Touching the keyboard is enough. However, Internet guarantees the access to knowledge without selecting the relevant one, being the reason why many people distinguishes access to information from access to knowledge. The search implies criteria at least to differentiate what is relevant and reliable from what is useless and doubtful.

Mastering these criteria requires a learning process in which the capacity to answer to questions such as "Where 
does the knowledge come from?", "How is it produced?", "What are the limitations of the applied research methods?", "How generalizable are they?" needs to be trained in a systematic and organized way.

So far, it seems that the university is the most prepared institution to offer training opportunities to acquire this skill, for a simple reason: those four questions are always used to introduce students to the research world. The university provides opportunities to cultivate the critical attitude regarding knowledge, that is, to develop a research attitude, and to know that without developing this critical attitude to understand the process of knowledge production, the professional preparation could become bookish marked only by the accumulation of knowledge as an end product.

Thus, radically reviewing the way professional preparation is been carried out is fundamental for the university to get out of its crisis. The present scenario puts in doubt the traditional model of teaching centered on transmission of information that persists in the university. It is necessary to review the objectives in order to introduce profound changes in the teaching contents and to adapt the methodologies to the modern times (e.g. Britto, 2009; Oliva, 2009). The university urgently needs to adapt the teaching process to the demands and facilities provided by both the knowledge and communication revolutions.

It is clear that the challenges faced by the university in the domain of professional preparation are not limited to the problems of the crisis mentioned here. The goal is to prepare professionals competent not only in intellectual, technical, behavioral, social, and political terms, but also socially responsible citizens. As was previously mentioned, this essay will not address these aspects of the professional preparation.

\section{Professional preparation: Brief history and perspectives}

As mentioned before, professional preparation is a complex process. It implies, before all, a philosophy that clearly defines the professional profile of the graduates. This profile strongly connects to the social needs and to the characteristics of labor market, both very dynamic in nature. Thus, defining competence within this profile is not a trivial task.

We can conceive the professional competence as the capacity to solve a problem in a given situation with high performance, which involves the application of a set of professional knowledge, skills, sensibilities and attitudes. Because of the diversity of problems and specificity of situations, competence cannot be a capacity described by a stock of finished and accomplished resources (Fleury \& Fleury, 2001), but a capacity endowed by means to face changes in the task and situation. Hence, competence is a dynamic capacity that implies flexibility and adaptability.

Present reflections about professional preparation include questions like: a) Which professional profile professional preparation programs must pursue? b) What type of professional would be better prepared to offer society a quality service to adequately attend their needs? c) What kind of professional competencies and sensibilities must a professional hold? d) Which professional is better, an autonomous person to continuously search for new knowledge or one dependent on external guidance and motivation? e) Which professional is better, a person capable of solving problems or one with the capacity to apply already established solutions? f) Which professional is better, one with acute sensibilities to make diagnosis of the conditions, necessities, and expectations of students and clients before prescribing activities or with capacity to prescribe activities only? (Tani, 2007).

An analysis of the historical process of professional preparation in physical education, with didactical purposes, shows some very characteristic phases. In the beginning, the guiding principle was "learn to execute movements to be able to teach them." In this phase, the goal of the professional preparation was to form a skilled performer by means of a curriculum with emphasis on subject matter oriented to practical activities. The basic content of the subject matter was technical knowledge and practical experiences of the elements of movement culture, that is, sport, games, exercise, gymnastics and dance. The pursued professional skill was the reproduction of movement techniques and the transmission of personal experiences. Considering the enormous number of physical education undergraduate courses offered by isolated colleges in Brazil, not universities, we speculate that many of them can still follow the aforementioned model of professional preparation.

In the next phase, the guiding principle changed to "learn to teach" in which the goal of the professional preparation was to form a competent teacher. In this perspective, curriculum emphasis was on pedagogically oriented subjects whose content was constituted by didactical procedures and teaching methods. The professional skill pursued was the elaboration and application of pedagogical sequences to teach the elements of movement culture. We speculate that the professional preparation in these isolated colleges of physical education, with this guiding principle, even at the present time, constitutes an innovative initiative.

In the last phase, which still belongs to the desirable domain not yet real, at least in the area of physical education, the guiding principle is "learn to learn" in which the goal of the professional preparation is to form a critical professional. In this perspective, the curriculum emphasis is on academically and scientifically oriented subjects whose content are academic and scientific knowledge, relative to the elements of the movement culture. The professional skill to pursue is the use of the scientific method to solve problems.

Summarizing the content already discussed, the professional preparation in an academically oriented profession implies in acquisition of an academic and scientific body of knowledge that gives support to projects, programs and procedures of professional intervention. Therefore, professional preparation at the University must 
give access to this body of knowledge. Nevertheless, this constitutes only a necessary condition when we consider that the university is under the influence of two revolutions: knowledge and communication revolutions. To adequately fulfill this condition, and to give access to knowledge at the same time, the university must develop a very crucial competence: learn to learn. On the contrary, it takes the risk of preparing "disposable" professionals because of quick knowledge obsolescence.

Thus, the challenge for professional preparation, which constitutes at the same time one possible alternative for the university to depart from the crisis, is how to put in practice the "learn to learn" guiding principle.

\section{Professional preparation and the cultivation of research attitude}

The labor market appraises professionals with a solid formation. Therefore, professional preparation programs have a good reason to offer quality teaching. People search for institutions that provide better teaching because they know that when they ask for a job the formation will be determinant.

However, entering in the labor market well prepared does not guarantee career progress and success. The incorporation of knowledge repertoire provided by the professional preparation programs is insufficient. It is necessary to continue the learning process throughout the career. As the professional preparation program offers a learning experience that lasts four years in average, and the professional career lasts approximately 35 years, according to the current labor legislation, what is really worth is the learning during the career.

In this sense, a high quality professional preparation program should be more concerned with the possibilities of progress throughout the career than with the content offered during the course. It needs to have the eyes directed to the future of people, society and labor market as demanded to any educational process. Hence, the question for the professional preparation is to identify what is that element with potential to make possible constant progress throughout the career.

We suggest that the research attitude developed by the process of "learn to learn" is a strong candidate. Obviously, there are other didactical and pedagogical means to promote "learn to learn" experiences in order to develop a research attitude, but it is important here to clarify the meaning of the research concept. Before all, research is an attitude taking process. That means, essentially, to feel unsatisfied with the status quo of the acquired knowledge and to have the determination to challenge the unknown world (Tani, 1995). To challenge the unknown world it is necessary curiosity and investigative attitude, which, in its turn, imply the capacity of reflection and critical spirit.

Thus, independently of following or not the career of researcher in the strict sense, all students must conclude their undergraduate course with a research attitude effectively cultivated and incorporated. That will guarantee continuous learning throughout the career that makes possible successfully perform their work in a constantly transforming labor market.

Unfortunately, the teaching model adopted in the professional preparation courses has privileged an informative process in detriment of a formative one (Guimarães, 1996). The informative process lead students to assume a passive attitude in relation to the search and acquisition of new knowledge. In this situation, learning characterizes a short-term memorization of bookish knowledge in which students do not have the opportunity to question and understand the process of its production; they incorporate knowledge as a finished and accomplished object. Student in the formative process, on the contrary, are stimulated to question and understand the process of knowledge production, cultivating a critical attitude in relation to the search and acquisition of new knowledge.

The best experience that the university can provide to students in their formative process in order to acquire a research attitude is the scientific initiation program. The role of the scientific initiation program is to introduce student in the universe of research in an organized and gradual way. Thus, the offering of a professional preparation program of formative character associated with the scientific initiation program makes possible a dynamic process of formation based on "learning to learn" leading to the development of a research attitude.

\section{Final remarks}

There is no doubt that the professional preparation must not aim to train professionals able to merely repeat means for solving practical problems, but professionals with the capacity to repeat the process of solving problems (Tani, 2007). That means that there is a need for more knowledgeable professionals who are capable of reflecting critically about problems, and putting them into a different perspective when appropriate and necessary (Ribeiro, 2005). Consequently, professional preparation programs need to be formative instead of informative and prepare professionals capable of using scientific thinking and method to solve practical problems of intervention.

In this process, the student staff must assume part of the responsibilities in the professional preparation (Tani, 2007). Indeed, a very important part. It is necessary, in the first place, a mentality change regarding the expectations that many students bring to the university. It is very common an expectation of having a course filled with practical activities enabling them to intensively enjoy the pleasures of physical activities especially the ones related to sports. As we know this expectation originates from an eminently practical conception of physical education constructed throughout their lives, strongly influenced by the experiences they had at school and by the society that cultivate, disseminate and even impose this conception. It is important to recognize that the professional preparation 
courses are essentially concerned with a body of knowledge historically constructed in the area. This mentality and expectation change will result in an attitude much more positive in relation to the search and acquisition of knowledge.

Another required mentality change refers to the difference between being a student and becoming a professional. Students must be conscious that since the first day of the course, they are gradually becoming professionals so they have to take care of their formation from the very beginning. Becoming professionals means to get specific habilitation in an area, which presupposes competence to assume the responsibility of offering quality service to the society, with ethics.

The transformation of mentality change in concrete actions (Tani, 2007) is the next step. The first necessary action is the students taking the role of subjects of their own learning process. This involves many aspects. For example, to understand that they should not study for a test, but to have access to a body of knowledge and build a solid structure that will become their instrument of work. Another action is to cultivate autonomy concerning the search for knowledge. It is important to understand that the contents offered by teachers in the classroom are just a small part of the immense repertoire of knowledge that they can access. This means to explore other sources of knowledge by themselves like libraries, laboratories, groups of study, courses, scientific events, conferences and so on to fulfill their curiosity, which has to be stimulated in the classroom. Furthermore, another important action is to keep connected to the innovations and technological developments to avoid becoming obsolete.

The second important responsibility students must take is the acquisition of a systemic view. Students must not reduce their university life to a simple process of knowledge acquisition in order to become able to solve practical problems in the future. It implicates that developing solid, comprehensive and deeper knowledge is a complex process. Hpefully, a student would be capable to critically think about general problems in the society (Tani, 1999). To acquire this systemic view, students must make good use of everything university offers and not limit their activities to the specific area of formation. The university offers a rich and diverse cultural, scientific, social and artistic agenda. They must explore all the available acculturation means like journals, sites, libraries, expositions, events, services, and so on.

In sum, students must understand from the beginning the relevance of "learn to learn" because knowledge can become obsolete quickly and the constant changing labor market demands increasingly high competencies. To perform new functions and play new roles that the social, economic, technological, scientific and cultural changes demand, there are requirements of long-term competencies that professionals must construct based on their solid initial formation and continuing formation process.

\section{References}

Britto, L. R. G. (2009). A universidade do futuro. In S. Vilela \& F. M. Lajolo (Orgs.), USP 2034: planejando o futuro (pp. 187207). São Paulo: Editora da Universidade de São Paulo.

Fleury, M. T. L., \& Fleury, A. (2001). Construindo o conceito de competência. Revista de Administração Contemporânea, 5 (n.esp.), 183-196.

Guimarães, J. A. (1996). Pós-Graduação e pesquisa. In Coordenação de Aperfeiçoamento de Pessoal de Nível Superior (Ed.), Discussão da pós-graduação brasileira (pp. 9-16). Brasília: Ministério da Educação e do Desporto.

Oliva, G. (2009). Modelo de universidade, missão e visão de futuro. In S. Vilela \& F. M. Lajolo (Orgs.), USP 2034: planejando o futuro (pp. 45-72). São Paulo: Editora da Universidade de São Paulo.

Ribeiro, R. J. (2005). Preparar os alunos para as transformações no mundo. In M. Rollemberg (Org.), Universidade: formação e transformação (pp. 63-66). São Paulo: Editora da Universidade de São Paulo.

Rollemberg, M. (Org.). (2005). Universidade: formação \& transformação. São Paulo: Editora da Universidade de São Paulo.

Steiner, J. E., \& Malnic, G. (Orgs.). (2006). Ensino superior: conceito e dinâmica. São Paulo: Editora da Universidade de São Paulo.

Tani, G. (1988). Pesquisa e pós-graduação em educação física. In S. C. E. Passos (Org.), Educação física e esportes na universidade (pp. 379-394). Brasília: SEED/MEC/UnB.

Tani, G. (1989). Perspectivas da educação física como disciplina acadêmica. In Anais do II Simpósio Paulista de Educação Física (Vol. 2, pp. 2-12). Rio Claro: Universidade Estadual Paulista.

Tani, G. (1995). Vivências práticas no curso de graduação em educação física: necessidade, luxo ou perda de tempo? In Anais do VI Simpósio de Pesquisa em Educação Física (pp. 17-31). Florianópolis: Universidade Federal de Santa Catarina.

Tani, G. (1996). Cinesiologia, educação física e esporte: ordem emanante do caos na estrutura acadêmica. Motus Corporis, 3 (2), 9-50.

Tani, G. (1998). 20 anos de ciências do esporte: um transatlântico sem rumo? Revista Brasileira de Ciências do Esporte, (n. esp.), 19-31.

Tani, G. (1999). Pós-graduação e iniciação científica. In Anais do VII Congresso de Educação Física e Ciências do Esporte dos Países de Língua Portuguesa (pp. 46-56). Florianópolis: Universidade Federal de Santa Catarina/Universidade Estadual de Santa Catarina.

Tani, G. (2006). Comportamento motor e sua relação com a educação física. Brazilian Journal of Motor Behavior, 1, 2130.

Tani, G. (2007). Avaliação das condições do ensino de graduação em Educação Física: garantia de uma formação de qualidade. Revista Mackenzie de Educação Física e Esporte, 6 (2), 55-70.

Tani, G. (2008). Área de conhecimento e intervenção profissional. In Pesquisa em comportamento motor: a intervenção profissional em perspectiva (pp. 14-25). São Paulo: Universidade de São Paulo.

Tani, G. (2010). Das pessoas às instituições: o Janus no ideário em educação física e ciências do desporto dos países lusófonos. Revista Portuguesa de Ciências do Desporto, 10 (1), 207-217.

Tani, G. (2011). A educação física e o esporte no contexto da universidade. Revista Brasileira de Educação Física e Esporte, 25 (n.esp.), 117-126. 


\section{Author's note}

Go Tani is a faculty member of the School of Physical Education, University of São Paulo

\section{Correspondence}

Av. Prof. Mello Moraes, 65

Cidade Universitária

São Paulo, SP 05508-030

E-mail: gotani@usp.br

This study was presented as part of an invited lecture at the $8^{\text {th }}$ International Congress of Physical Education and Human Movement and $14^{\text {th }}$ Symposium Paulista Physical Education.

Declaration of Conflicting Interests: The author declared no conflicts of interest exist with respect to the research, authorship, and/or publication of this article.

Manuscript received on March 30, 2013

Manuscript accepted on May 10, 2013 